\section{DE DE GRUYTER} OPEN

G

Krzysztof Wach*

Cracow University of Economics
Journal of Intercultural Management

Vol. 6, No. 3, September 2014, pp. 177-186

DOI 10.2478/joim-2014-0028

\title{
Familiness and Born Globals: Rapid Internationalisation among Polish Family Firms ${ }^{1}$
}

\begin{abstract}
Rapid internationalisation is a very popular research theme internationally. Verifying the links between familiness of the investigated firms and the accelerated internationalisation among Polish family firms can be very promising. The objective of the paper is to identify the rapid internationalisation path of Polish family firms while going international from the comparative perspective of the familiness. The paper presents the research results of the survey conducted in the turn of 2013-2014 among 216 firms, including 88 family businesses. Based on the calculations we can assume that the average time of internationalisation measured from the establishment is the longer in case of family firms than non-family firms. It can be with the line to the statement that born globals are more frequently met among non-family firms.
\end{abstract}

Key words: born global, internationalisation, international entrepreneurship, small and medium-sized enterprises, family firms, family entrepreneurship

\section{Introduction}

On the average in the EU just about $71 \%$ of all businesses can be regarded as family firms [Surdej, Wach 2010, p. 108-109], the highest ca. 90\% or more in Cyprus, Estonia, Spain, Germany, Italy and the lowest ca. 35\% in Latvia, Lithuania and Poland. However, it is estimated that in Poland, family businesses constituted from $35 \%$ (prudent estimates) to about $70-80 \%$ (optimistic estimates) of the total number of Polish firms [Surdej, Wach 2011, p. 5, pp. 135-136]. Family businesses are

\footnotetext{
This article came into being within the research project no. StG-21310034 entitled 'Patterns of Business Internationalization in Visegrad Countries - In Search for Regional Specifics' financed by the International Visegrad Grand IVF and conducted by five Central European universities coordinated by Cracow University of Economics.
}

*wachk@uek.krakow.pl 
one of the most important sources of wealth generation and employment growth in the contemporary world. More and more researchers would like to explore and explain the phenomenon of family firms and their role in the economy. Family business (FB) has been regarded as a separate scientific field since 1990s [Shi 2014, p. 3]. It has its prestigious international journals, book series and scientific associations. Nevertheless, various researchers representing various scientific disciplines ad hoc undertake the research on family businesses from the different perspectives, mainly from macroeconomics (role of FBs in economic growth and development), management (ownership and coordination of the FBs) and entrepreneurship (the role of family as the entrepreneur, family entrepreneurship). In the literature there is a definition dilemma and the terms such as family business (FB), family firm (FF), family-controlled firm (FCF), family-owned business (FOB) are used [Shi 2014, p. 3; Litz 2008, p. 218], however the most accepted approach distinguishes the Three-Circle Model linking the family, the ownership and the management [Davis, Taguiro 1982; Jaffe 1990; Cohn 1992, Hatten 2003; Surdej, Wach 2012; Więcek-Janka, 2013].

Since over two decades scientists all over the world have been trying to explain international aspects of family business [Popczyk 2013; Zaniewska 2012; Kontinen, Ojala 2010; Hadryś-Nowak 2014; Wach \& Wojciechowski, 2014; Daszkiewicz \& Wach, 2014; Daszkiewicz, 2014]. The objective of the paper is to identify the rapid internationalisation path of Polish family firms while going international from the comparative perspective of the familiness. The paper presents the research results of the survey conducted in the turn of 2013-2014 among 216 firms, including 88 family businesses.

\section{Theoretical Background of the Rapid Internationalisation: Born Globals}

Already in 1989 an Israeli researcher J. Ganitsky noticed innate exporters on the basis of his research conducted in Israel [Knight, Madsen, Servais 2004, p. 649]. It is reported that the born globals were first identified in the early 1990s in Australia in a report prepared by McKinsey \& Co [1993]. As a result of the research results the economist S.T. Cavusgil [1994a; 1994b] announced the end of the era of stages models. The above mentioned report defines a born global as a firm which from the inception perceives the world as its marketplace, hence the foreign markets are not addenda to the domestic market [Wach 2012; Wach 2014]. The report identifies two groups of exporters - traditional exporters and small business born globals. The latter within two years of their launch achieved $76 \%$ of their revenues from exports, while their average age was 14 years old, and together these companies provided $20 \%$ of Australian exports [Rennie 1993, p. 46].

One of the first quoted definition of born globals can be found in G.A. Knight and S.T. Cavusgil [1996 quoted in Persinger, Civi, Walsh, Vostina 2007, p. 74]. Gen- 
erally born globals are defined as small businesses with fewer than 500 employees whose annual turnover does not exceed 100 million USD, and the share of exports (one or several of its products) is at least $25 \%$ of the total production volume during the first two years. A similar definition can be found in later studies, for example it is most often reported that born globals in the first two or three years of operation generate at least $25 \%$ of the total turnover of the business in foreign markets [Knight, Madsen, Servais 2004, p. 649; Moen 2002, p. 158]. A lot of controversy to the definitions of born globals being the hackneyed and duplicated in different studies, are arisen in the literature, however stressing that they are appropriate only for highly developed economies, and having little adequate for emerging markets and developing economies [Persinger, Civi, Walsh, Vostina 2007; Lopez, Kundu, Ciravegna 2009].

B.M. Oviatt and P.P. McDougall [1994] created of the concept of international new ventures (INV), which de facto gave rise to the emergence of international entrepreneurship as a separate academic discipline. The international new venture is a business organisation that from the inception tries to gain a significant competitive advantage from the use of resources and sales in many countries [Oviatt, McDougall 1994, p. 49]. The INV concept is readily apparent from the adversarial over conventional stages models. The main difference relates to the process of internationalisation of the firm per se, which runs here faster and more aggressively, and firms can bypass conventional fixed stages of internationalisation. It is worth noting that B. M. Oviatt and P.P. McDougall in their assumptions did not specify the exact moment of the internationalisation of international new ventures, and incidentally identified four types of such ventures [1994, p. 59]:

- an export / import start-up meaning the internationalisation of the firm engaged in the trade on few markets in the slight need for coordination of activities in these markets, except for logistics,

- a multinational trader specifying a trader operating in many markets, however, mainly in the form of exporting and importing, while the more markets it operates in, the more needs to intensify the coordination of activities,

- a geographically focused start-up, which means the firm internationalised on a scale of a region of the world, using tacit knowledge to build a competitive advantage difficult to imitate, which can be identified with the later developed in the literature the concept of born regional [Lopez, Kundu, Ciravegna 2009], - a global start-up, which is a pure form of a born global.

Firms classified in the first two categories of international new ventures are known as the creators of a new international market. These are traditional firms that focus primarily on the export and import in several or many foreign markets. The theory of international new ventures is sometimes also referred to models of instant internationalisation, internationalisation at founding, or the theories of 
early internationalisation. International new ventures seek to gain a niche in the global market, where they get to use more effective strategies for internationalisation [Hallbäck, Larimo 2007, p. 42]. As a rule, already in the initial stage they act simultaneously on several or even many markets. The process approach can be recognised in the development through these four ventures, due to the transition between the four types of ventures highlighted by Oviatt and McDougall. It occurs also that the firms from the beginning are born globals (as one of the four types).

\section{Methodological Assumptions of the Empirical Research}

The research objective of the paper is to identify the rapid internationalisation path of Polish family firms while going international from the comparative perspective of the familiness and to explore the born globals among investigated family firms. In the course of the study, the following research hypotheses were assumed:

H1: The average time of internationalisation measured from the establishment is the same for family and non-family firms.

H2: Born globals are more frequently met among non-family firms.

The two main research methods were applied: literature review, its critics and synthesis as well as the survey. The questionnaire (a telephone conversation request followed by an e-mail with the online password-protected questionnaire) was sent to 6000 Polish firms being listed in the database of Polish exporters. The survey was conducted between October 2013 and February 2014 (Wach \& Wojciechowski, 2014; Daszkiewicz \& Wach). However the return of questionnaires was 248 firms, nevertheless to further statistical analysis only 216 firms, including 88 family firms could be accepted (fig. 1). The survey questionnaire, having 27 complex questions, was divided into four parts:

1. characteristics of the firm,

2. characteristics of the entrepreneur being an owner or a principal manager,

3. characteristics of the business industry,

4. patterns of business internationalisation.

The statistical calculations were made by means of the statistical software package "Stata/SE 12.0". Pearson's chi-square independence test as well as test comparing two means were applied in order to verify the assumed hypotheses. 
Figure 1. Size of the family and non-family firms in the sampling

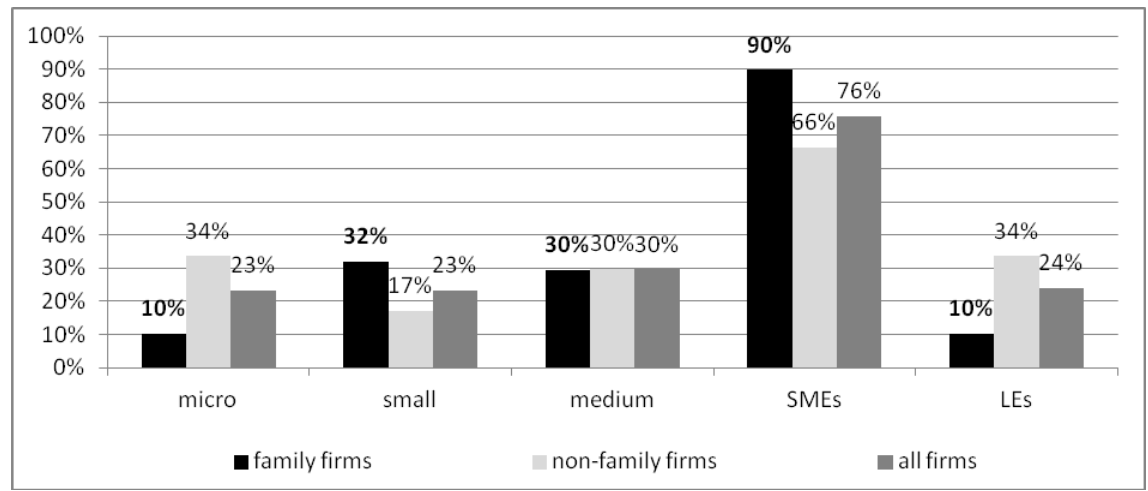

Source: Own study based on the research results $(\mathrm{N}=216$, where Nfamily $=88)$

\section{Empirical Results and Discussions}

Four out of ten investigated firms internationalise according to the traditional path, while six firms internationalise much faster and use the rapid internationalisation path (fig. 2). This relation is a bit higher on the plus of born globals ${ }^{2}$ for nonfamily firms. Slightly less than half of family firms use traditional and slower path of the internationalisation. By testing differences between two means $(z=2.853>$ 1.644), it can be proved that family firms internationalise longer than non-family firms (table 1, table 2).

Figure 2. Traditional and rapid internationalisation among family and non-family firms

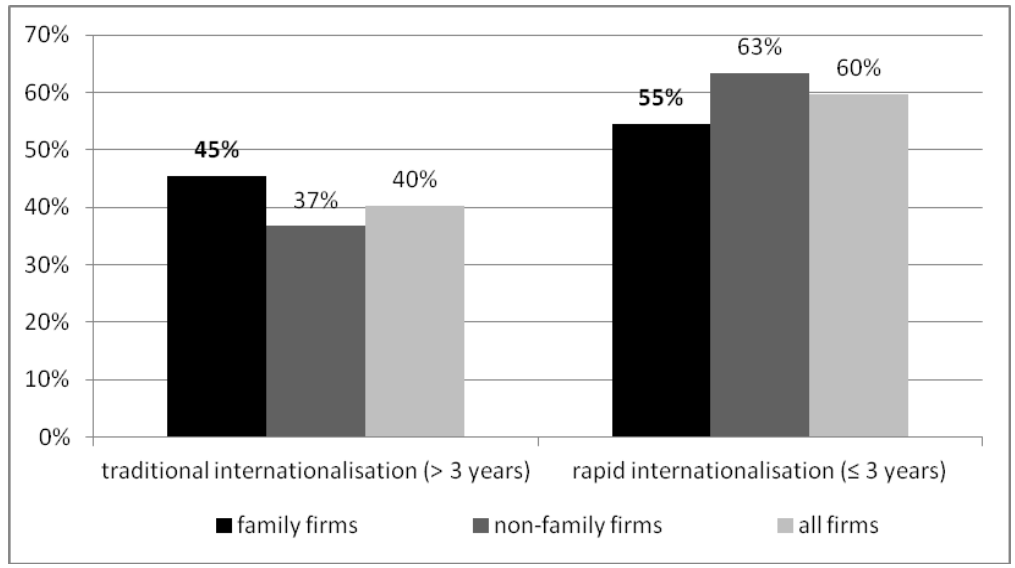

Source: Own study based on the research results $(\mathrm{N}=216$, where $\mathrm{Nfamily}=88)$

2 Born globals are understood in here as firms, which internationalise within 3 years after the establishment. 
Table 1. Descriptive statistics for the speed of internationalisation

\begin{tabular}{|l|c|c|}
\hline Statistics & Family firms & Non-family firms \\
\hline Mean & 5 & 3 \\
\hline Median & 2 & 1 \\
\hline Lowe quartile & 0 & 0 \\
\hline Upper quartile & 8 & 4 \\
\hline Standard deviation & 6.4 & 4.3 \\
\hline
\end{tabular}

Source: Own study based on the research results $(\mathrm{N}=216$, where $\mathrm{Nfamily}=88)$

Table 2. Detailed descriptive statistics for the internationalised family firms

\begin{tabular}{|l|c|c|c|c|c|}
\hline Statistics & $\begin{array}{c}\text { Establishment } \\
\text { (year) }\end{array}$ & $\begin{array}{c}\text { Expansion } \\
\text { (year) }\end{array}$ & $\begin{array}{c}\text { Int'l Time } \\
\text { (years) }\end{array}$ & $\begin{array}{c}\text { Staff (per- } \\
\text { sons) }\end{array}$ & $\begin{array}{c}\text { Foreign } \\
\text { capital (\%) }\end{array}$ \\
\hline mean & 1991 & 2000 & 9 & 111.6 & 13 \\
\hline min & 1855 & 1904 & 0 & 1 & 0 \\
\hline max & 2013 & 2013 & 140 & 3602 & 100 \\
\hline sd & 23 & 12.5 & 20 & 392.6 & 29.6 \\
\hline median & 1994 & 2001 & 2.5 & 25 & 0 \\
\hline Q1 & 1990 & 1996 & 0 & 5.5 & 0 \\
\hline Q3 & 2001 & 2008 & 11.5 & 87.5 & 1 \\
\hline cv & 0.011 & 0.006 & 2.232 & 3.2518 & 2.274 \\
\hline
\end{tabular}

Source: Own study based on the research results $($ Nfamily=88)

There is a relation between the size and speed of internationalisation (chi2 = 144.4564, $\mathrm{df}=120, \mathrm{p}=0.064)$. However the results can be controversial as we don't know the size when they internationalized (only the current size). The fastest internationalisation, that is in the year of establishment, occur among medium-sized and microenterprises as well as large enterprises (fig. 3). After one year from the establishment the internationalisation was very popular among small firms. Altogether 76 out of 216 firms were internationalised from the inception (31 firms after a year, 14 after 2 consecutive years, 8 after three years and 11 firms after 4 years).

In the questionnaire the responders were asked to determine which of the four basic strategic approaches are used. There were four descriptive options (fig. 4), which later on were transformed into a clear names of the strategies. The statistical calculations (chi2 $=14.5950 \mathrm{dr}=3, \mathrm{p}=0.002$ ) prove that there is a dependence between the familiness of the investigated firms and their strategies (fig. 5). Traditional internationalisation is the most popular among family firms, while born regionals and born globals ${ }^{3}$ are more often met among non-family firms. choice.

Born globals are understood in here as firms that declare such a status based on the description 
Figure 3. Size of the firms and their traditional and rapid internationalisation

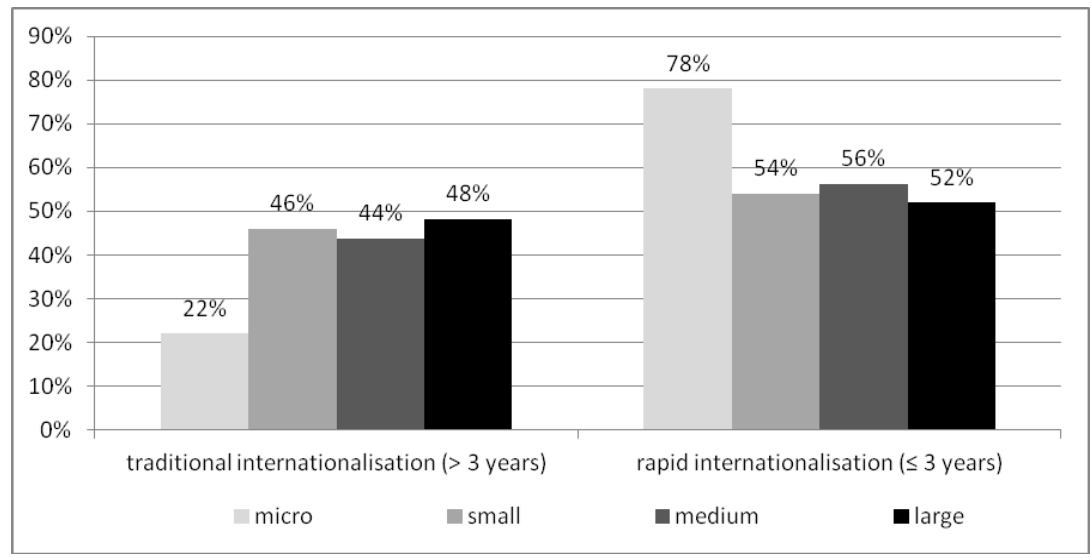

Source: Own study based on the research results $(\mathrm{N}=216$, where $\mathrm{Nfamily}=88)$

Figure 4. Internationalisation patterns according to the survey questionnaire

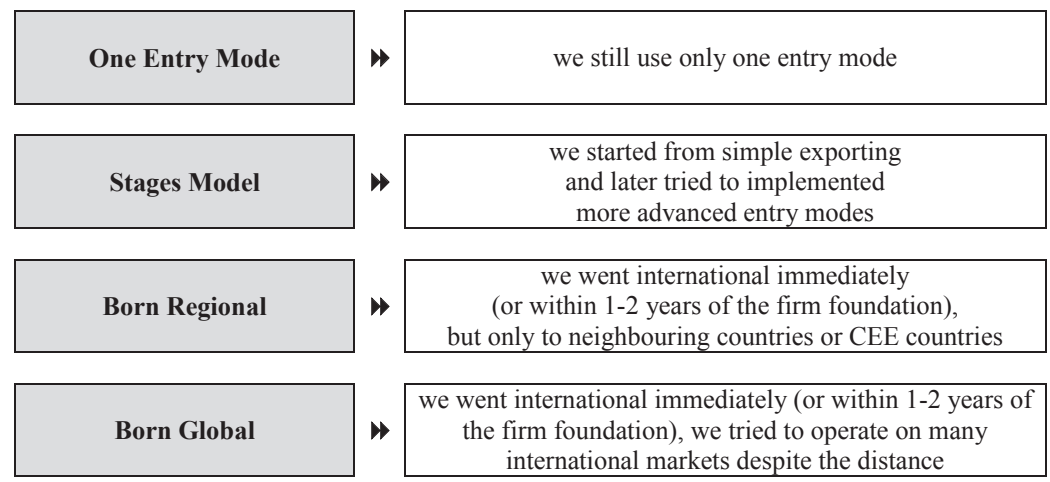

Source: Own study based on the research questionnaire

\section{Conclusions}

Some basic conclusions based on the survey results and statistical calculations can be drawn up, however they must be treated as a kind of very initial poll results only. Nevertheless, further detailed research using a much wider sampling of internationalised family firms is needed in order to present more detailed and precise conclusions.

The hypothesis $\mathrm{H} 1$ was rejected as it was proved that the average time of internationalisation measured from the establishment is longer in case of family firms than non-family firms. On the average the investigated family firms internation- 
alised within 9 years since the establishment. It can be with the line to the hypothesis $\mathrm{H} 2$, which was proved, stating that born globals are more frequently met among non-family firms. It is just against the research conducted in Poland by W. Popczyk [2013, p. 10 and 215], however on a peculiar sampling of companies listed on NewConnect, so they are not representative for all Polish family businesses.

Figure 5. Internationalisation patterns among family and non-family firms

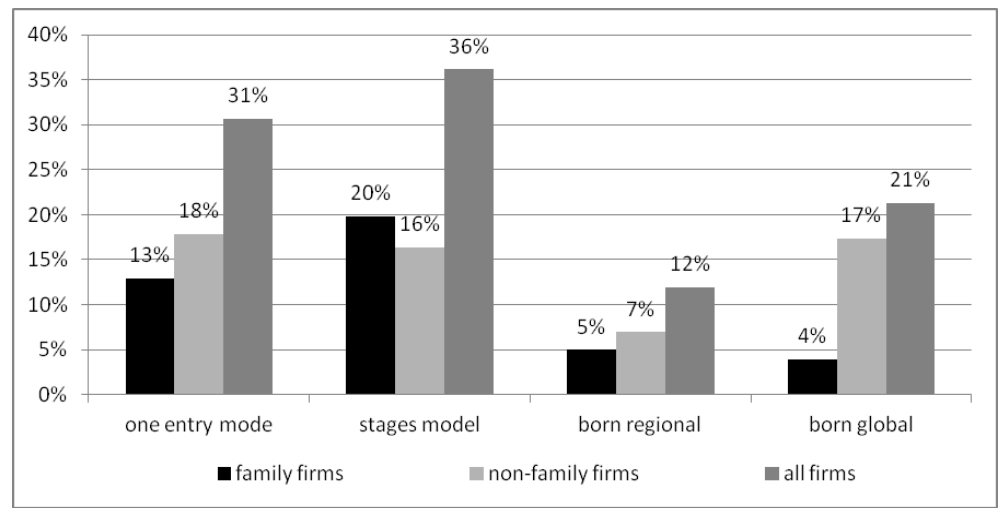

Source: Own study based on the research results $(\mathrm{N}=216$, where $\mathrm{Nfamily}=88)$

\section{Bibliography}

Cavusgil S.T. (1994a), A Quit Revolution in Australian Exporters, Marketing News, vol. 28, no. 11, pp. $18-21$.

Cavusgil S.T. (1994b), Born Globals: A Quiet Revolution Among Australian Exporters, Journal of International Marketing Research, vol. 2, no. 3, pp. 4-6.

Cohn M. (1992), Passing the Tourch, Succession, Retirement \& Estate Planning in Family - Owned Business, New York: McGraw-Hill Inc.

Daszkiewicz, N. (2014), Internacjonalizacja polskich firm rodzinnych z perspektywy przedsiębiorczości międzynarodowej, Prz̨edsiębiorczość i Zarzqdzanie, 2014, t. XV, z. 7, cz. 1.

Daszkiewicz N., Wach K., (2012), Internationalization of SMEs. Context, Models, Implementation, Gdańsk University of Technology Publishers, Gdańsk 2012.

Daszkiewicz N., Wach K., (2013), Małe i średnie przedsiębiorstwa na rynkach międzynarodowych, Wyd. Uniwersytetu Ekonomicznego w Krakowie, Kraków 2013.

Daszkiewicz, N., Wach, K. (2014), Motives for Going International and Entry Modes of Family Firms in Poland, Journal of Intercultural Management, vol. 6, no. 2.

Davis J. A., Tagiuri R. (1982), Bivalent attributes of the family firm, Owner Managed Business Institute, Santa Barbara, CA.

Hadryś-Nowak, A. (2014), Internationalization of Polish Family-owned Businesses - Owner and Next 
Generation Perspective. In: B. Knežević, K. Wach (eds), International Business from Central European Perspective, University of Zagreb, Zagreb, pp. 53-64.

Hallbäck J. Larimo J. (2007), Variety in International New Ventures - Typological Analysis and Beyond, Journal of Euromarketing, vol. 16, no. 1-2, pp. 37-57.

Hatten T.S. (2003), Small Business Management. Entrepreneurship and Beyond, 2nd edition, Boston: Houghton Mifflin.

Jaffe D.T. (1990), Working with Ones you Love: Conflict Resolution and Problem Solving Strategies for a Successful Business, Canari: Berkeley C.A.

Knight G.A., Cavusgil S.T. (1996), The Born Global Firm: A Challenge to Traditional Internationalization Theory, Advances in International Marketing, vol. 8, pp. 11-26.

Knight G.A., Madsen T.K., Servais P. (2004), An Inquiry into Born-global Firms in Europe and the USA, International Marketing Review, vol. 21, no. 6, pp. 645-665.

Kontinen, T, Ojala, A. (2010). The internationalization of family businesses: a review of extant research, Journal of Family Business Strategy, vol. 1, no. 2.

Litz R.A., (2008): Two Sides of a One-Sided Phenomenon: Conceptualizing the Family Business and Business Family as a Möbius Strip, Family Business Review, vol. 31, no. 3.

Lopez L.E., Kundu S.K., Ciravegna L. (2009), Born Global or Born Regional? Evidence from an Exploratory Study in the Costa Rican Software Industry, Journal of International Business Studies, vol. 40, pp. 1228-1238.

Marjański A., Sułkowski L. (2009), Firmy rodżinne. Jak osiagnaí sukces w sżtafecie pokoleń, Poltext, Warszawa.

McKinsey \& Co. (1993), Emerging Exporters: Australia's High Value-Added Manufacturing Exporters, McKinsey and Company - Australian Manufacturing Council, Melbourne.

Moen Ø. (2002), The Born Globals. A New Generation of Small European Exporters, International Marketing Review, vol. 19, no. 2, pp. 156-175.

Oviatt B.M., McDougall P.P. (1994), Towards a Theory of International New Ventures, Journal of International Business Studies, vol. 25, no. 1, pp. 45-64.

Persinger E.S., Civi E., Walsh Vostina S. (2007), The Born Global Entrepreneur in Emerging Economies, International Business \& Economics Research Journal, vol. 6, no. 3, pp. 73-82.

Popczyk W. (2013), Przedsiębiorstwa rodzinne w otoczenin globalnym. Analiza porównawcza ekspansji miedzynarodowej firm rodzinnych i nierodzinnych z rynku NewConnect, Wydawnictwo Uniwersytetu Łódzkiego, Łódź.

Rennie M.W. (1993), Born Global, McKinsey Quarterly, vol. 4, pp. 45-52.

Safin K. (2007), Prz̨edsiebiorstwo rodzinne - istota $i$ zachowania strategiczne, Wydawnictwo Akademii Ekonomicznej im. O. Langego we Wrocławiu, Wrocław.

Shi H.X. (2014), Entrepreneurship in Family Business. Cases from China, (Series: International Studies in Entrepreneurship, Vol. 30), Springer, Cham - Heildelberg - New York - London.

Surdej A., Wach K. (2010), Prz̨edsiębiorstwa rodzinne wobec wyzwań sukcesji, Difin, Warszawa. 
Surdej A., Wach K. (2011), Succession Choices in Family Firms. The Case of Poland, Wydawnictwo Aadam Marszałek, Toruń.

Surdej A., Wach K. (2012), The Dynamics of Succession in Family Businesses in Poland Empirical Results, Economia Marche. Journal of Applied Economics, vol. 31, no. 2, pp. 109-128.

Wach K. (2012), Europeizacja malych i średnich przedsiębiorstw: rozwój przez. umiędzynarodowienie, PWN, Warszawa 2012.

Wach K. (2013), An Empirical Investigation into the EU Policy in Favour of Business Succession among Polish Family Firms, Horyzonty Polityki vol. 4, nr 9, s. 107-133.

Wach K. (2014), Przedsiębiorczość międzynarodowa jako nowy kierunek badan w obrebie teorii internacjonalizacji przedsiębiorstwa [w:] Tradycyjne i nowe kierunki rozwoju bandlu miedzynarodowego, red. S. Wydymus, M. Maciejewski, CeDeWu, Warszawa.

Wach, K., Wojciechowski, L., The Size and the Strategic International Orientation: The Use of EPRG Model among Polish Family and Non-Family Firms, Przedsiebiorczośc $i$ Zarzadzanie, 2014, t. XV, z. 7, cz. 1, s. 143-156.

Więcek-Janka, E. (2013), Wiodace wartości w zarąqdzaniu pržedsiębiorstwem rodżinnym, Wydawnictwo Politechniki Poznańskiej, Poznań.

Zaniewska K. (2012), Determinants of family business internationalization. Review of existing research, Economia Marche Journal of Applied Economics, 2012, vol. XXXI, no. 2. 